\title{
An overlooked threatened species of eagle: Legge's Hawk Eagle Nisaetus kelaarti (Aves: Accipitriformes)
}

\author{
J. O. GJERSHAUG ${ }^{1,4}$, O. H. DISERUD ${ }^{1}$, P. C. RASMUSSEN ${ }^{2} \&$ D. WARAKAGODA ${ }^{3}$ \\ ${ }^{1}$ Norwegian Institute for Nature Research, Tungasletta 2, NO 7485 Trondheim, Norway. \\ E-mail: jan.o.gjershaug@nina.no,ola.diserud@nina.no \\ ${ }^{2}$ Michigan State University Museum and Department of Zoology, Michigan State University, West Circle Drive, East Lansing, MI \\ 48824-1045, USA. E-mail: rasmus39@msu.edu \\ ${ }^{3} 9 / 2$ a, Station First Lane, Udahamulla, Nugegoda, Sri Lanka. E-mail: drongo@sltnet.lk \\ ${ }^{4}$ Corresponding author. Email: jan.o.gjershaug@nina.no
}

\begin{abstract}
Species delimitation is fundamental to many areas of biology, and in cases where taxonomic status has not been sufficiently clarified the ramifications can be as serious as extinction due to the failure to implement conservation measures. Since 1931, the Mountain Hawk Eagle Nisaetus (Spizaetus) nipalensis Hodgson has included the allopatric Sri Lankan and southern Indian taxon $N$. kelaarti (Legge) as a subspecies, and its taxonomic status has not been re-evaluated. We found that $N$. kelaarti differs considerably from $N$. nipalensis in its relatively much larger bill and claws and short primary projection, and that it also differs consistently in numerous plumage characters and other mensural characters. Its vocalizations differ distinctly, and an earlier study found a moderate degree of genetic differentiation $(4.4 \%$ in cyt $\mathrm{b}$ and $3.1 \%$ in CR) from N. nipalensis. The available evidence thus strongly and unambiguously supports the specific distinctness of $N$. kelaarti.
\end{abstract}

Key words: taxonomy, phylogeography, vocalization, Spizaetus nipalensis, Mountain Hawk Eagle, India, Sri Lanka

\section{Introduction}

Species delimitation is essential to biogeography, ecology, macroevolution, and conservation biology (Brown et al. 1996; Blackburn \& Gaston 1998; Barraclough \& Nee 2001; Rasmussen 2005; Agapow et al. 2004). Regardless of which species concept is applied, assigning specific status to allopatric taxa will inevitably remain somewhat arbitrary. Under the Biological Species Concept (BSC) there have been only vague guidelines as to how allopatric populations should be treated (Mayr \& Ashlock 1991). Recently, Helbig et al. (2002) worked out more detailed guidelines for assigning species rank. According to their criteria, allopatric taxa should be considered species if they are fully diagnosable in each of several discrete or continuously varying characters related to different functional contexts, e.g. structural features, plumage colours, vocalizations, or DNA sequences, or some combination of these, and when the sum of the character differences corresponds to or exceeds the level of divergence seen in related species that exist in sympatry.

When the first large hawk-eagle specimen was taken in Sri Lanka, it was considered identical to the Mountain Hawk Eagle Nisaetus nipalensis of the Himalayas by all authors, few of whom had actually examined the specimen (Jerdon 1862; Blyth 1866; Holdsworth 1872; Sharpe 1874). Only when three additional specimens became available was it apparent that the Sri Lankan form was distinctive, and Legge then named it as a new species $N$. kelaarti (Legge 1878). Subsequently, Peters (1931) treated N. kelaarti as a subspecies of 
$N$. nipalensis. Although no published justification was given for this lumping, to our knowledge no author has treated N. kelaarti as a distinct species subsequently (e.g., Sibley \& Monroe 1990). The nominate subspecies is distributed from the Himalayas of Pakistan to western China, subspecies $N$. $n$. orientalis Temminck and Schlegel occurs in Japan, whereas N. kelaarti occurs in the Western Ghats of south-western India and the hills of Sri Lanka (del Hoyo et al. 1994; Ferguson-Lees \& Christie 2001). The genetic difference between $N$. nipalensis and $N$. kelaarti averages $4.4 \%$ in mtDNA cyt b and $3.1 \%$ in the mitochondrial control region (Haring et al. 2007).

Nisaetus kelaarti has been described as smaller than N. nipalensis by several authors (Brown \& Amadon 1968; del Hoyo et al. 1994; Ferguson-Lees \& Christie 2001; Rasmussen \& Anderton 2005), mostly based on differences in wing length. Brown and Amadon (1968) described N. kelaarti as rather paler than N. nipalensis, about the same size or a little smaller and scarcely distinct, and del Hoyo et al. (1994) claimed that $N$. kelaarti differs from nominate N. nipalensis only in smaller size. Rasmussen and Anderton (2005) found that total length, tail length (measured from the distal end of the pygostyle) and foot (tarsus plus length of longest toe and claw to tip) were smaller in $N$. kelaarti than in $N$. nipalensis. None of these authors mentioned that $N$. kelaarti has larger toes, claws, and bill than $N$. nipalensis, although Legge $(1878,1880)$ described the large foot with its huge claws.

Previous assessments of the distinctiveness of $N$. kelaarti have been hampered by the small number of available specimens and marked age-related variation. The finding that $N$. kelaarti differs considerably from $N$. nipalensis in mtDNA prompted us to re-evaluate morphological and vocal differentiation between $N$. kelaarti and $N$. nipalensis, and from these new data we conclude that they should be regarded as distinct species.

\section{Material and methods}

We use the genus name Nisaetus instead of Spizaetus because, as formerly recognized, the latter genus is polyphyletic, with different clades in Asia, South America, and Africa (Gamauf et al. 2005; Helbig et al. 2005; Haring et al. 2007).

Morphological measurements and plumage studies were carried out at The Natural History Museum, Tring (BMNH). Measurements were taken using calipers and a ruler. A total of 26 adult and immature specimens representing two taxa ( $21 \mathrm{~N}$. nipalensis, $5 \mathrm{~N}$. kelaarti---see Appendix) were measured for 13 variables: flattened wing length, Kipp's distance = primary projection (distance from the tip of longest tertial to the wingtip), tail length (measured from the insertion of the central rectrices), tarsus length, bill length from cere, bill breadth (measured immediately anterior to the cere), bill depth, length of hind toe, middle toe, hind claw, middle claw and crest (length of the longest crest feather), number of dark tail bands, and extent of tarsal feathering (distance feathering extends onto the toes beyond the distal end of the tarsus, located by palpation). Because birds not fully grown could add an age effect (juveniles of many raptors have different feather lengths than do adults), we excluded juveniles from the mensural data set. Several digital photographs were taken of each BMNH specimen of $N$. kelaarti, and a specimen database was created from museum and literature reports. Photographs of three additional specimens of $N$. kelaarti were sent from other museums (see Appendix).

The sex of most museum skins was given on the label, however we also used a PCA to sex individuals. We supported the PCA results by plotting bill length versus hind claw of individuals of each taxon, similar to the predictive model used by Bortolotti (1984).

Birds were placed in four age classes on the basis of their rectrices: 1) Those with all juvenile rectrices (fully grown) were considered juveniles; 2) those with at least one second-generation rectrix and at least one retained juvenile rectrix were considered $1^{\text {st }}$-stage immatures; 3 ) those with at least one third-generation 
(adult) rectrix and at least one retained second-generation (immature) rectrix were considered $2^{\text {nd }}$-stage immatures; and 4) those with entirely adult (third-generation) rectrices were considered adults.

We distinguished juvenile from adult rectrices by their narrower tail bands, the dark ones more irregularly spaced with the subterminal pale band much the broadest band, and therefore widely separating the distalmost dark band from the penultimate dark band. Second-generation rectrices are intermediate in pattern between juvenile and adult rectrices but closer to adult rectrices. Birds in category 2 could thus be distinguished by the distinct difference in pattern between their retained juvenile and new second-generation rectrices.

To compare the two taxa with respect to different morphological variables, we used a standard two-sample $\mathrm{t}$-test to determine if the observed difference between sample means was significant. Before the t-tests were run, we performed an F-test to check if the two variances could be treated as being equal. If the variances were found to be equal, the pooled variance was applied in the t-test. With unequal variances, the probability of a Type I error will tend to differ from the chosen significance level; in these cases we applied the Welch approximation to the degrees of freedom (see e.g. Zar 1999) to compensate for this departure.

We used principal component analysis (PCA) to help explain mensural variability within and among individuals, sexes, and taxa. This multivariate method uses the correlation structure among variables to identify underlying, independent principal components (PCs), which are linear functions of the original variables that may explain the dimensions associated with high data variability (see e.g. Afifi \& Clark 1998). The first few PCs typically explain most of the variation in the original data, and some operational meaning can be attached to the PCs to aid in their interpretation. Our PCA analysis was based on a correlation matrix to allow scaling to unit variance. All statistical analyses were performed using the free statistical software R (http://www.rproject.org).

Sonograms from calls of N. kelaarti from Sri Lanka (DW and Paul Holt), N. n. nipalensis from Bhutan (Paul Holt) and North India (Paul Holt and JOG), and N. $n$. orientalis from Japan (Toru Yamazaki and from Kabaya and Matsuda [2001]) were made using Gram23 (downloadable from WinSite), after which background noise was removed in Adobe Photoshop CS2. For qualitative vocal descriptions, conventions used in Rasmussen and Anderton (2005) were followed. In these, differential letter size indicates relative amplitude of elements, with ALL CAPS indicating loudest, SMALL CAPS indicating moderate amplitudes, and lower case indicating softest elements, while "" indicates that the following note is at a lower pitch than the preceding element. We use the term "strophe" to indicate all the elements of a closely spaced series of notes followed by a distinct pause.

\section{Results}

Biometry and plumage of Nisaetus nipalensis and N. kelaarti

Statistical analysis of the biometrical variables revealed significant differences between $N$. nipalensis and $N$. kelaarti in eight variables (Table 1). Nisaetus nipalensis has significantly longer wing, Kipp's distance (primary projection), tail, and tarsus than does $N$. kelaarti. However, $N$. kelaarti is larger than N. nipalensis in bill length, bill depth, hind toe and claw, and middle toe and claw. Using PCA we found that one individual of $N$. kelaarti had clearly been incorrectly sexed.

The PCA plot in Fig. 1 indicates a taxon and sex separation of the individuals along the two first principal components. The first principal component (PC1) explains $43 \%$ of the total variance, whereas the second component (PC2) explains 20\% (Table 2). The sexes were segregated without overlap on PC1, whereas the taxa N. nipalensis and N. kelaarti separated without overlap on PC2.

Major plumage differences between adults and juveniles of $N$. nipalensis and N. kelaarti are summarized in Tables 3 and 4, and illustrated in Fig. 3a-d. The two taxa differ in both adult and juvenile plumages, but they are more similar in juvenile and immature plumages than in adult plumage. 
TABLE 1. Biometrics and differences between Nisaetus nipalensis and N. kelaarti. The p-value is obtained by a twosample t-test. $\mathrm{F}=$ female, $\mathrm{M}=$ male. For $N$. kelaarti we have only one female, so we cannot perform any test, but we have indicated if the $N$. kelaarti individual is more extreme than any of the $N$. nipalensis females by an asterisk $(*)$.

\begin{tabular}{|c|c|c|c|c|c|c|c|c|}
\hline \multirow[t]{2}{*}{ Morph. character } & \multirow[t]{2}{*}{ Sex } & \multicolumn{3}{|c|}{ N. nipalensis } & \multirow[t]{2}{*}{ p-value } & \multicolumn{3}{|c|}{ N. kelaarti } \\
\hline & & $\mathrm{n}$ & mean & st.dev. & & $\mathrm{n}$ & mean & st.dev. \\
\hline \multirow[t]{2}{*}{ Wing length } & $\mathrm{M}$ & 9 & 437.2 & 10.3 & $<0.001$ & 4 & 407.5 & 6.5 \\
\hline & $\mathrm{F}$ & 12 & 479.2 & 14.6 & 1) & 1 & 455.0 & \\
\hline \multirow[t]{2}{*}{ Kipp's dist. } & M & 9 & 92.8 & 13.3 & $<0.01$ & 4 & 61.3 & 20.2 \\
\hline & $\mathrm{F}$ & 12 & 113.8 & 9.6 & $*$ & 1 & 45.0 & \\
\hline \multirow[t]{2}{*}{ Tail length } & M & 8 & 281.3 & 8.3 & n.s. & 4 & 275.0 & 9.1 \\
\hline & $\mathrm{F}$ & 12 & 297.9 & 16.4 & & 1 & 310.0 & \\
\hline \multirow[t]{2}{*}{ Hind toe } & M & 9 & 27.5 & 3.8 & $<0.05$ & 4 & 33.6 & 2.7 \\
\hline & $\mathrm{F}$ & 12 & 29.9 & 2.2 & $*$ & 1 & 36.2 & \\
\hline \multirow[t]{2}{*}{ Middle toe } & M & 9 & 39.5 & 2.3 & $<0.0001$ & 4 & 48.9 & 1.2 \\
\hline & $\mathrm{F}$ & 12 & 44.3 & 3.2 & $*$ & 1 & 52.2 & \\
\hline \multirow[t]{2}{*}{ Hind claw } & M & 9 & 38.7 & 1.7 & $<0.001$ & 4 & 43.2 & 1.2 \\
\hline & $\mathrm{F}$ & 12 & 46.0 & 1.9 & $*$ & 1 & 52.9 & \\
\hline \multirow[t]{2}{*}{ Middle claw } & M & 9 & 25.7 & 2.0 & $<0.05$ & 4 & 28.4 & 0.9 \\
\hline & $\mathrm{F}$ & 12 & 29.6 & 1.9 & & 1 & 30.1 & \\
\hline \multirow[t]{2}{*}{ Tarsus length } & M & 9 & 110.3 & 6.0 & $<0.10$ & 4 & 103.3 & 6.7 \\
\hline & $\mathrm{F}$ & 12 & 114.8 & 5.5 & & 1 & 117.0 & \\
\hline \multirow[t]{2}{*}{ Bill length } & M & 9 & 30.2 & 1.9 & $<0.01$ & 4 & 33.7 & 0.0 \\
\hline & $\mathrm{F}$ & 12 & 33.9 & 1.3 & $*$ & 1 & 38.0 & \\
\hline \multirow[t]{2}{*}{ Bill breadth } & M & 9 & 14.0 & 0.9 & n.s. & 4 & 14.5 & 0.5 \\
\hline & $\mathrm{F}$ & 12 & 16.0 & 1.1 & $*$ & 1 & 19.6 & \\
\hline \multirow[t]{2}{*}{ Bill Depth } & M & 9 & 20.9 & 1.4 & $<0.05$ & 4 & 22.6 & 0.4 \\
\hline & $\mathrm{F}$ & 11 & 23.8 & 1.0 & $*$ & 1 & 27.5 & \\
\hline \multirow[t]{2}{*}{ Crest length } & M & 9 & 91.1 & 16.9 & n.s. & 4 & 86.5 & 4.1 \\
\hline & $\mathrm{F}$ & 12 & 78.8 & 21.5 & & 1 & 90.5 & \\
\hline \multirow[t]{2}{*}{ Tail bands } & M & 9 & 4.7 & 0.5 & n.s. & 4 & 5.0 & 0.0 \\
\hline & $\mathrm{F}$ & 12 & 4.9 & 0.3 & & 1 & 5.0 & \\
\hline
\end{tabular}

*: The female of $N$. kelaarti is larger than the largest $N$. nipalensis in tail length, foot and bill characters

${ }^{1)}$ : The wing length of the female $N$. kelaarti equals that of the smallest nipalensis female $N$. nipalensis.

Adults of N. kelaarti are illustrated in Fig. 3-5. In adult plumage, N. nipalensis has a darker head, especially on crown and side of the face, heavier throat streaks and darker breast streaks than $N$. kelaarti. The breast and flanks of $N$. nipalensis have darker, browner (vs. pale rufescent) barring than in $N$. kelaarti. The underwing coverts and upper tail coverts are also more strongly barred in $N$. nipalensis than in N. kelaarti. The tail pattern in N. kelaarti shows less contrast between the dark and pale bands than in N. nipalensis. In N. kelaarti, the tarsi are less thickly feathered, the tarsal feathers are shorter, and the feathering is less extensive on the toes than in $N$. nipalensis.

In juvenile plumage $N$. kelaarti has very broad bands of rufescent brown and whitish cinnamon on breast and belly, whereas juveniles of $N$. nipalensis normally lack any patterning below. The tail pattern of $N$. kelaarti has fewer dark bands than in N. nipalensis. In $N$. kelaarti, most of the dark tail bands are narrower than the pale bands, whereas they are broader than the pale ones in N. nipalensis. The longest uppertail coverts 
are much paler and contrast with the lower back and tail in N. nipalensis, whereas these areas are concolorous in N. kelaarti.

TABLE 2. Loadings and total variance of the two first principal components for the morphological characters of Nisaetus nipalensis and $N$. kelaarti.

\begin{tabular}{lll}
\hline Character & PC1 & PC2 \\
\hline Wing length & 0.30 & 0.40 \\
Kipp's distance & 0.11 & 0.54 \\
Tail length & 0.31 & 0.18 \\
Hind toe & 0.16 & -0.45 \\
Middle toe & 0.27 & -0.32 \\
Hind claw & 0.40 & -0.06 \\
Middle claw & 0.31 & 0.00 \\
Tarsus length & 0.18 & 0.34 \\
Bill length & 0.33 & -0.24 \\
Bill breadth & 0.34 & -0.01 \\
Bill depth & 0.39 & -0.09 \\
Crest length & -0.13 & -0.11 \\
Tail bands & 0.16 & -0.11 \\
\hline Total variance & $43 \%$ & $20 \%$ \\
\hline
\end{tabular}

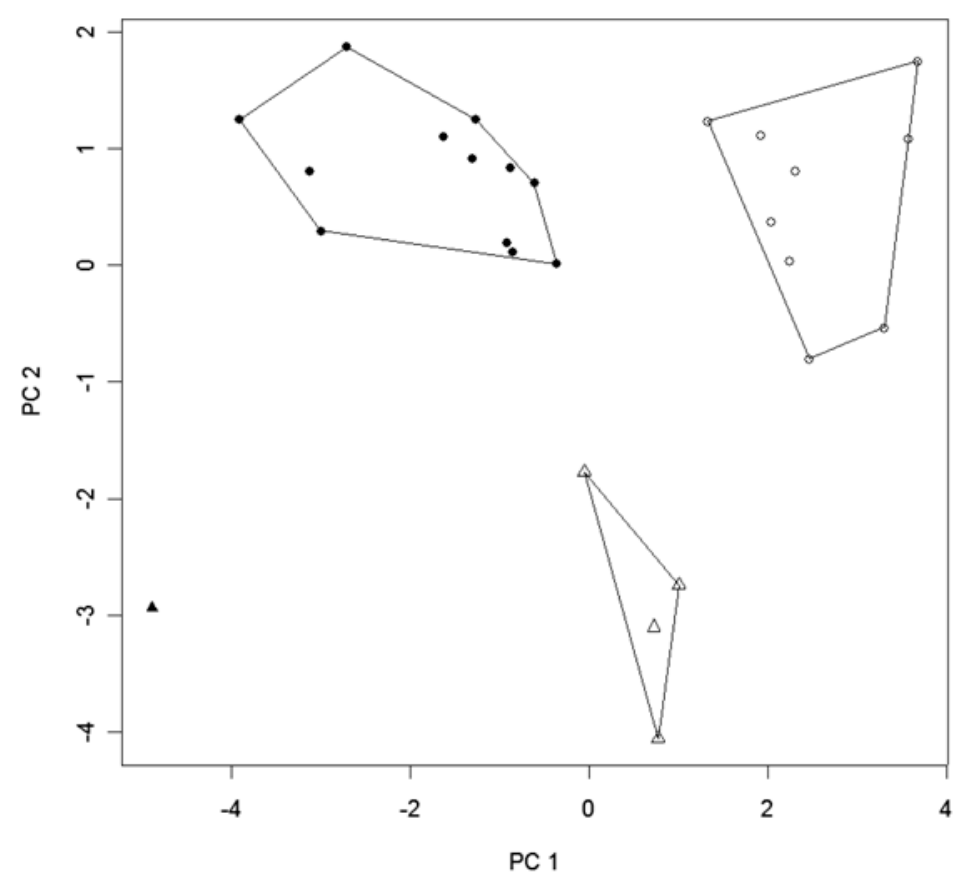

FIGURE 1. Results of a Principal Component Analysis (PCA) of biometrics. Empty circles indicate Nisaetus nipalensis males and filled circles $N$. nipalensis females. Empty triangles indicate $N$. kelaarti males and filled triangles $N$. kelaarti females.

In both taxa there is a gradual plumage development from juvenile plumage to full adult plumage via two intermediate immature plumages. Due to the gradual development of adult plumage it is difficult to differenti- 
ate between the two immature year classes except by the type of rectrices present. Stage 2 immature rectrices are more adult-like than are stage 1 immature rectrices, and juvenile rectrices are very distinctive.

Legge's (1878) description was based on three specimens from Ceylon (Sri Lanka), but these have not been traced. BMNH 1955.6 N20.388 may be one of the syntypes, although it was not identified as such by Warren (1966). Legge $(1878,1880)$ described a difference between $N$. kelaarti and $N$. nipalensis in the white bars of the belly and thigh. In N. nipalensis he stated that these bars are divided by a dark spot at the shaft, whereas on $N$. kelaarti there are no such dark bars. However, we found that among skins of N. nipalensis, several adults did not conform to this, while one specimen of $N$. kelaarti resembled most $N$. nipalensis in this feature. Another character in Legge's description was that the bars continue higher up the breast on $N$. kelaarti than in any $N$. nipalensis he had seen, but this putative difference is not obvious to us. It appears that $N$. kelaarti has some paedomorphic features, because adults retain immature plumage features, for example the head patterning and the colour of the underparts barring.

\section{Vocalizations}

Qualitative and quantitative descriptions and sonograms of vocalizations of $N$. $n$. nipalensis are presented in Rasmussen and Anderton (2005), but no recordings of N. kelaarti were then available. Descriptions of vocalizations of Mountain Hawk Eagle are also given by Naoroji (2006), but without indication of the provenance and thus of the taxon they represent.

The vocalization of adult $N$. kelaarti in flight shown in Fig. 2a differs strikingly from any known vocalization of $N$. nipalensis. It is composed of much shorter notes than most of those recorded for N. nipalensis. We term this the "short call". The short call of $N$. kelaarti is a shrill, rapid, peevish, chattering CHI-CHI-CHNchew (see Methods for conventions of qualitative descriptions). A short call of $N$. nipalensis in flight from northern India (Fig. 2c) sounds quite different, being unhurried and deliberate, and can be represented as (?)-FWEEtu (the first element not being audible in the recording).

The other available recording almost certainly of $N$. kelaarti and believed to be of a bird in flight, shown in Fig. 2b, is very different from that in Fig. 2a, and is referred to here as the "long call". While the attribution of this recording to $N$. kelaarti needs to be verified, it does not match any other known species and was confidently identified by a very reliable local guide, Shajimom Paul, who accompanied Paul Holt at Periyar. The Periyar recording can be rendered as a relatively high-pitched, squealing, insistent kip-FEEEU, FEEEEU, the first note faintest, short and staccato, the other two notes well-separated, rather drawn-out piercing whistles at a near-constant frequency (c. $4 \mathrm{kHz}$ ), nearly identical in length, the third note being slightly longer, and each attenuating in amplitude and dropping slightly but rapidly in pitch at the end. As can be seen from Fig. 2, no

FIGURE 2. Sonograms and waveforms of vocalizations of Nisaetus kelaarti and $N$. nipalensis. (2a) adult N. kelaarti in flight, 31 December 2002, Nuwara Eliya, 2050 m, Sri Lanka, recordist DW. (2b) putative N. kelaarti, not seen (call identified by local guide Shajimom Paul) but thought to be in flight, 1 December 2005, Periyar National Park, Kerala, India, 930 m, recordist Paul Holt. (2c) adult N. n. nipalensis in flight 8 February 2005, Kumeria, Uttaranchal, northern India, $635 \mathrm{~m}$, recordist JOG (for the second strophe in $2 \mathrm{c}$, the first element (at about $2.5 \mathrm{~s}$ ) was obscured by talking and for purposes of the figure was added in based on the first element of the first strophe in the sequence). No waveform is presented as the recording was very distant. (2d1-3) presumed juvenile N. nipalensis perched about $300 \mathrm{~m}$ distant, near Deban, Namdapha National Park, Arunachal Pradesh, India, 24 February 1998, recordist Paul Holt. All vocalizations from the same individual, numbered in chronological order. (2e1-6) adult N. nipalensis in flight, north of Thimpu, western Bhutan, 26 February 1995, recordist Paul Holt. All vocalizations from the same individual, numbered in chronological order. 2e5 is incomplete, as the recording started after the sequence had already begun (indicated on sonogram by ...). (2f) N. n. orientalis, Japan, from recording in Kabaya and Matsuda (2001). (2g1-2) juvenile N. n. orientalis in July 1990 in Suzuka Mountains, Japan, $500 \mathrm{~m}$, recordist Toru Yamazaki. Waveforms, placed at $6 \mathrm{kHz}$ for each sonogram, provide information on absolute and relative amplitude of elements in the vocalizations. 

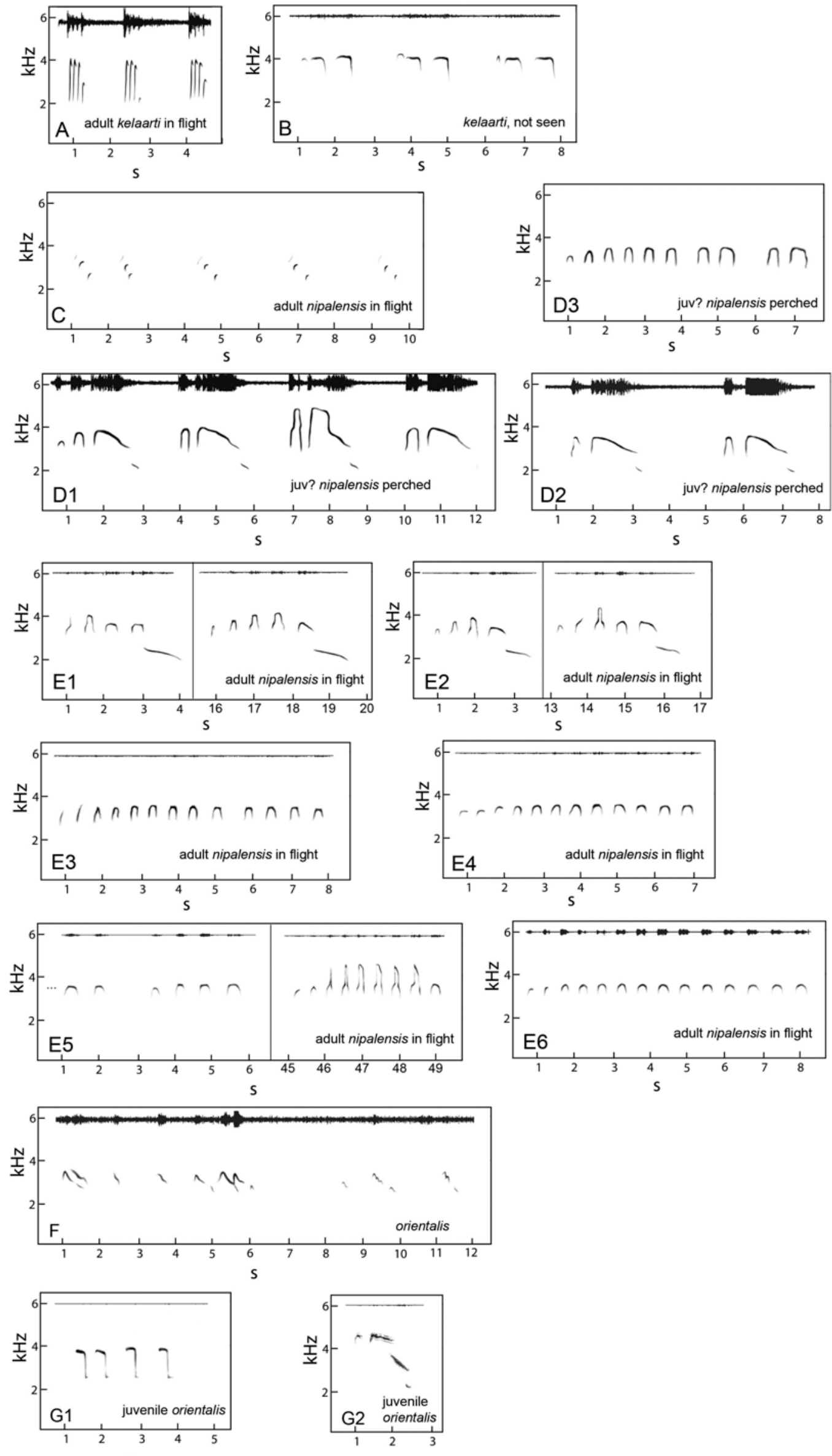
available recording of $N$. nipalensis matches this. Except for the introductory notes which are occasionally very short, notes in the long series of $N$. nipalensis (especially Fig. 2d3) differ from those in the long call of $N$. kelaarti in being much more modulated in frequency; they are distinctly up- and then downslurred, with very little time at the frequency apex, while those of $N$. kelaarti are held at $4 \mathrm{kHz}$ for virtually their entire duration.

In addition, both available recordings of $N$. kelaarti are higher-pitched than most notes of $N$. nipalensis, with the exception of "cracked" notes of N. nipalensis (e.g., the third strophe of Fig. 2d1, and most of the notes in Fig. $2 \mathrm{e} 5$ between 46 and 49 s).

As shown in Fig. $2 \mathrm{f}$ and $\mathrm{g}$, the vocalizations of the Japanese subspecies $N$. $n$. orientalis are yet again somewhat different from either of the above. However, given that those of Fig. $2 \mathrm{~g}$ are from a juvenile, and that the context is unknown for that in Fig. $2 \mathrm{f}$, further recordings are needed to interpret the significance of these apparent differences. Inoue Takehiko (in litt. to JOG) described the vocalizations of adult $N$. $n$. orientalis as lower and longer than those of $N$. n. nipalensis, sounding like " $B u-B u, B u-B u$ " when the birds are being cautious, as when they are near their nest site.


FIGURE 3. BMNH specimens in ventral view: (a) Nisaetus kelaarti, adult on left, four immatures in middle, juvenile on right; (b) Nisaetus nipalensis, three adults on left, two juveniles on right. Same specimens on dorsal view: (c) N. kelaarti; (d) N. nipalensis.

\section{Discussion}

On the basis of the large number of diagnostic differences between $N$. kelaarti and N. nipalensis, we recommend that $N$. kelaarti should be treated as a distinct species, and propose to resurrect the English name Legge's Hawk Eagle after the naturalist who described the species to science (Legge 1878). This name also has a long history of use specifically for this taxon by Henry (1978), Wijesinghe (1994) and earlier authors. Other names historically used include Ceylon Mountain Hawk Eagle, Feather-toed Hawk Eagle and Beautiful Crested Eagle (Kelaart 1853; Legge 1880; Henry 1978). 
The morphological differences between the taxa suggest the likelihood of ecological differences between them. The depth, breadth, and length of the bill, and the length of the hind claw are related to the mode of handling and killing prey. Bird-hunting raptors typically have longer claws on their middle toes and shorter hind claws and shorter bill compared to mammal specialists (Wattel 1973; Brown 1976; Hertel 1995; Gamauf et al. 1998; Preleuthner \& Gamauf 1998). This suggests that N. kelaarti may take a higher proportion of mammals than does $N$. nipalensis.

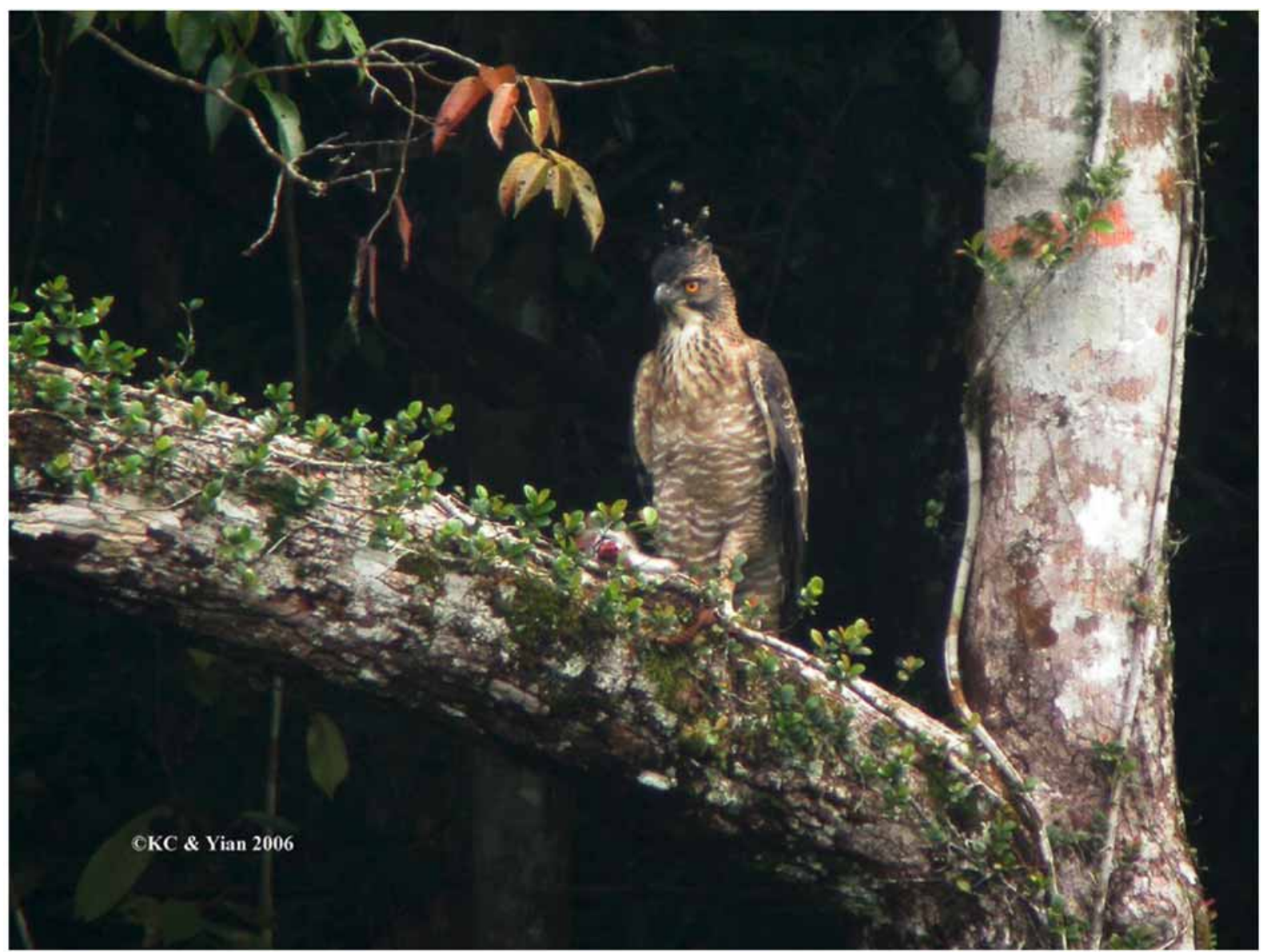

FIGURE 4. Adult Nisaetus kelaarti photographed in Sinharaja Nature Reserve in Sri Lanka by Lim Kim Chye.

The shape (Kipp's distance) and the length of the wing, hind toe, tarsus, and middle toe are probably related to hunting technique. Wing length is not a good measure of overall size in $N$. kelaarti because of its very short primary projection (Kipp's distance), probably correlated with hunting inside forests and its lack of migratory behaviour (Kipp 1959). As with most Himalayan birds, N. nipalensis migrates altitudinally in the Himalayas, young birds sometimes even wandering to central India (Rasmussen \& Anderton 2005), whereas N. kelaarti is probably sedentary.

In addition, the genetic difference between $N$. kelaarti and $N$. nipalensis is on average $4.4 \%$ in mtDNA cyt $b$. However, as the average difference was only $3.1 \%$ in CR, it indicates that the cyt $b$ value may be exaggerated. Founder effects in small relict rainforest habitats during dry periods of the Pleistocene may be an explanation (Haring et al. 2007). In the proposed assignment of species rank to allopatric taxa, Helbig et al. (2002) recommended that the taxa be assigned species rank if they are fully diagnosable in each of several discrete or continuously varying characters related to different functional contexts, e.g. structural features, plumage colours and DNA sequences. We find that $N$. kelaarti is diagnosable in several structural features (wing, toe, claw and bill) (Table 1), 13 plumage differences (Tables 2, 3), in vocalizations (Figure 2) and in DNA sequences (Haring et al. 2007). We consider that the large number of diagnosable characters indicates that $N$. kelaarti is a distinct species, regardless of which species concept is used. 


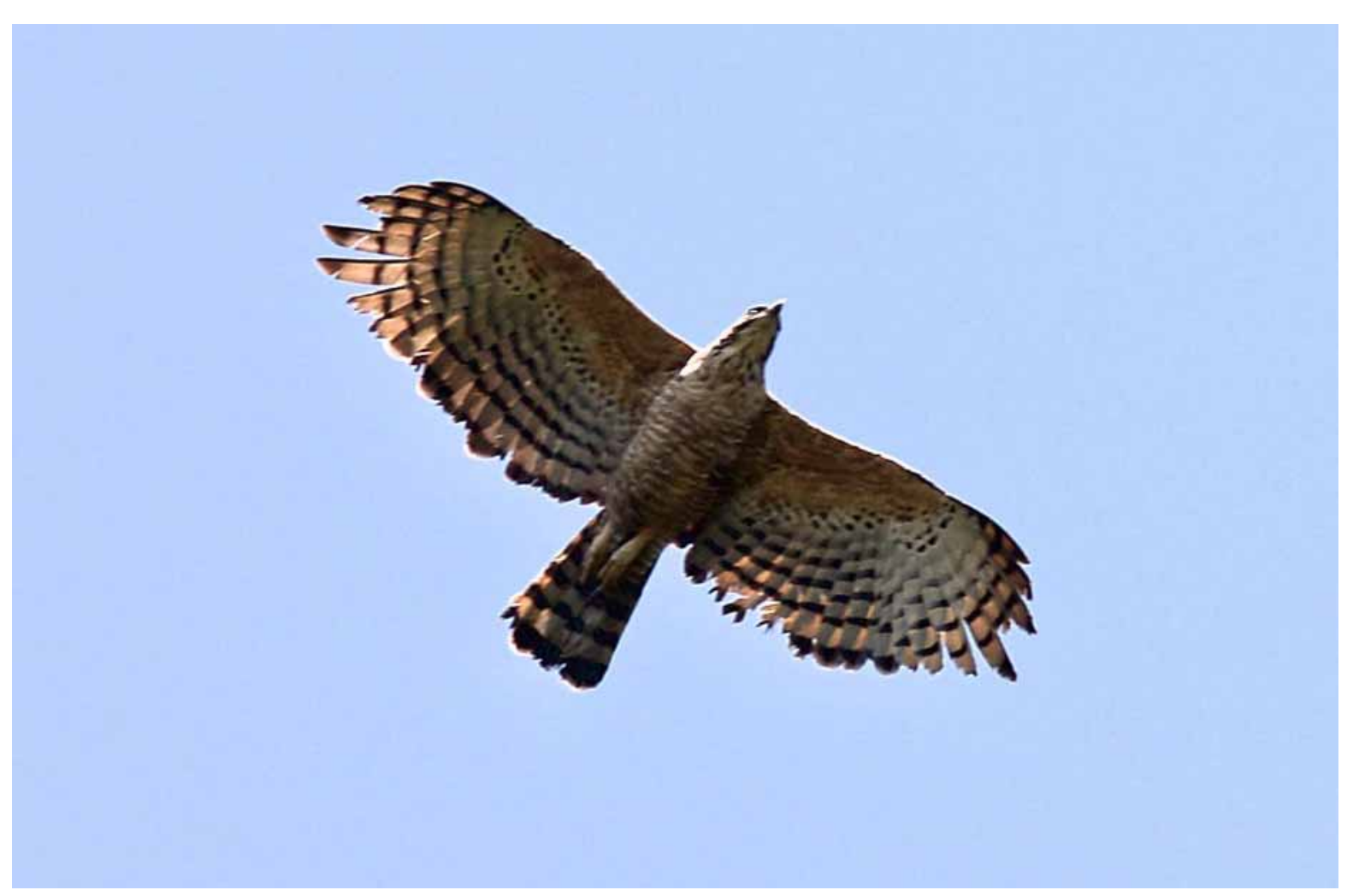

FIGURE 5. Adult Nisaetus kelaarti photographed in Sri Lanka by Uditha Hettige.

TABLE 3. Main plumage differences between adult Nisaetus kelaarti and $N$. nipalensis. $\mathrm{N}=$ number of individuals.

\begin{tabular}{|c|c|c|}
\hline Character & N. kelaarti & N. nipalensis \\
\hline Crown and side of face & Light brown & Blackish \\
\hline Crest & $\begin{array}{l}\text { Broader, with more mid-length feathers } \\
(10-11, N=3) \text { surrounding the long feathers }\end{array}$ & $\begin{array}{l}\text { Narrower, with fewer mid-length feathers } \\
(4-7, N=6)\end{array}$ \\
\hline Throat streak & $\begin{array}{l}\text { Absent or nearly so in three males, strong } \\
\text { but thin in female }\end{array}$ & Heavy in all birds \\
\hline Breast markings & $\begin{array}{l}\text { Few dark streaks restricted to upper breast, } \\
\text { and the lower ones are very thin dark } \\
\text { streaks surrounded by rufous-brown tear- } \\
\text { drop-shaped marks }\end{array}$ & Heavier and more uniform dark streaks \\
\hline Underwing coverts & $\begin{array}{l}\text { Solid rufous-cinnamon to weakly check- } \\
\text { ered darker cinnamon and whitish }\end{array}$ & $\begin{array}{l}\text { Very heavily barred with blackish and } \\
\text { white }\end{array}$ \\
\hline Uppertail coverts & Almost uniform dark brown & Strongly barred dark brown and white \\
\hline Tail pattern & $\begin{array}{l}\text { Uppertail surface shows less contrast } \\
\text { between the dark and pale bands }\end{array}$ & $\begin{array}{l}\text { Pale bands outlined by whitish in most } \\
\text { birds, thus contrasting more to the dark } \\
\text { bands }\end{array}$ \\
\hline Feathers of tarsi & $\begin{array}{l}\text { Almost unmarked all pale on distal part of } \\
\text { tarsus }\end{array}$ & $\begin{array}{l}\text { Heavy markings reach top of toes in most } \\
\text { birds. }\end{array}$ \\
\hline Extent of feathering on toes & $\begin{array}{l}\text { Barely extends onto pes digit } 3 \text {; feathering } \\
\text { extends } 12.0-14.2 \mathrm{~mm}(\mathrm{~N}=3) \text { beyond tarsal } \\
\text { joint }\end{array}$ & $\begin{array}{l}\text { Extends distinctly farther onto pes digit 3; } \\
\text { feathering extends } 15.2-22.2 \mathrm{~mm}(\mathrm{~N}=7) \\
\text { beyond tarsal joint }\end{array}$ \\
\hline
\end{tabular}


This new species status has implications for conservation. Legge's Hawk Eagle will probably be listed as Vulnerable on the Global Redlist (Gjershaug et al. in prep.). This sparsely-distributed species has small and declining populations, and although it is somewhat tolerant of habitat fragmentation, its conservation will require preservation of large areas of rainforest.

TABLE 4. Main plumage differences between juvenile $N$. kelaarti and $N$. nipalensis. $\mathrm{N}=$ number of individuals with retained juvenile rectrices.

\begin{tabular}{|c|c|c|}
\hline Character & kelaarti & nipalensis \\
\hline Breast and belly & $\begin{array}{l}\text { Very broad bands of rufescent } \\
\text { brown and whitish cinnamon }\end{array}$ & $\begin{array}{l}\text { Normally lack any patterning below, but a few } \\
\text { have fine, vague cinnamon barring from lower } \\
\text { belly to longer tarsal plumes }\end{array}$ \\
\hline Number of dark tail bands & $5-6(\mathrm{~N}=3)$ & $7-8(\mathrm{~N}=21)$ \\
\hline Tail pattern & $\begin{array}{l}\text { Most dark bands narrower than } \\
\text { pale brown bands }\end{array}$ & $\begin{array}{l}\text { Most dark bands are broader than the pale ones, } \\
\text { often much broader }\end{array}$ \\
\hline Longest uppertail coverts & $\begin{array}{l}\text { Not much paler than the uppertail } \\
\text { surface, and fairly uniform in colour }\end{array}$ & $\begin{array}{l}\text { Banded pale brown and whitish, wearing to all- } \\
\text { whitish, contrasting with lower back and tail }\end{array}$ \\
\hline
\end{tabular}

\section{Acknowledgments}

We thank R. P. Prys-Jones at The Natural History Museum (BMNH), Tring, for permission to take photos of skins, and M. P. Adams for help with photography; copyright remains with BMNH. We owe thanks to A. Gamauf and E. Haring for comments on an earlier draft. Photographs were sent of additional specimens by K. Zyskowski (Yale Peabody Museum, YPM), S. Kenney (American Museum of Natural History, AMNH), and G. Jathar (Bombay Natural History Society, BNHS). P. Holt provided recordings from India and Sri Lanka. T. Yamazaki provided recordings from Japan, I. Takehiko provided information on vocalizations in Japan, C. Milensky (USNM) provided some recording details, and S. Butchart gave valuable comments. We thank Lim Kim Chye for allowing use of his photograph in Fig. 4 and U. Hettige for use of the photograph in Fig. 5.

\section{References}

Afifi, A.A. \& Clark, V. (1998) Computer-Aided Multivariate Analysis, Chapman \& Hall, London, UK, 455 pp.

Agapow, P.M., Bininda-Edmonds, O.R.P., Crandall, K.A., Gittleman, J.L., Mace, G.M. et al.( 2004) The impact of species concept on biodiversity studies. Quarterly Review of Biology, 79, 161-179.

Barraclough, T.G. \& Nee, N. (2001) Phylogenetics and speciation. Trends in Ecology and Evolution, 16, 391-399.

BirdLife International (2001) Threatened birds of Asia: the BirdLife International red data book, BirdLife International, Cambridge, U. K., 3038 pp.

Blackburn, T.M. \& Gaston, K.L. (1998) Some methodological issues in macroecology. American Naturalist, 51, 68146883.

Blyth, E. (1866) The ornithology of India. A commentary on Dr. Jerdon's 'Birds of India'. Part 1. Ibis (NS), 7, 225-258.

Bortolotti, G.R. (1984) Sexual size dimorphism and age-related size variation in Bald Eagles. Journal of Wildlife Management, 48, 72-81.

Brown, L. (1976) Birds of prey, their biology and ecology, Hamlyn Publishing Group, Feltham, U.K.

Brown, J.H., Stevens, G.C. \& Kaufman, D.M. (1996) The geographic range: size, shape, boundaries, and internal structure. Annual Review of Ecology and Systematics, 27, 597-623.

Brown, L. \& Amadon, D. (1968) Eagles, hawks, and falcons of the world, Country Life Books, London.

Ferguson-Lees, J. \& Christie, D.A. (2001) Raptors of the world, Christopher Helm, London, 992 pp.

Gamauf, A., Gjershaug, J.O., Kvaløy, K., Røv, N. \& Haring, E. (2005) Molecular phylogeny of the hawk-eagles (genus Spizaetus). Zoologische Mededelingen, Leiden, 79-3, 179-180. 
Gamauf, A., Preleuthner, M. \& Winkler, H. (1998) Philippine birds of prey: interrelations among habitat, morphology, and behaviour. Auk, 115, 713-726.

Haring, E., Kvaløy, K., Gjershaug, J.O., Røv, N. \& Gamauf, A. (2007) Convergent evolution of the hawk-eagles of the genus Spizaetus: molecular phylogenetic analysis based on mitochondrial marker sequences. Journal of Zoological Systematics and Evolutionary Research, 45, 353-365.

Helbig, A., Knox, A.G., Parkin, D.T., Sangster, G. \& Collinson, M. (2002) Guidelines for assigning species rank. Ibis, $144,518-525$.

Helbig, A.J., Kocum, A., Seibold, I. \& Braun, M.J. (2005) A multi-gene phylogeny of aquiline eagles (Aves: Accipitriformes) reveals extensive paraphyly at the genus level. Molecular Phylogeny and Evolution, 35, 147-164.

Henry, G.M. (1978) A guide to the birds of Ceylon. K. V. G. de Silva \& Sons, Kandy, Sri Lanka, 457 pp.

Hertel, F. (1995) Ecomorphological indicators of feeding behavior in recent and fossil raptors. Auk, 112, 890-903.

Holdsworth, C.J. (1872) Catalogue of the birds found in Ceylon; with some remarks on their habits and local distribution, and descriptions of two new species peculiar to the island. Proceedings of the Zoological Society of London, 1872, 404-483.

del Hoyo, J., Elliott, A. \& Sargatal, J. (eds) (1994) Handbook of the birds of the world. Vol. 4. Lynx Edicions, Barcelona, $679 \mathrm{pp}$.

Jerdon, T.C. (1862) The birds of India. Vol. 1. Calcutta: published by the author, 534 pp.

Kabaya, T. \& Matsuda, M. (2001) The songs and calls of 420 birds in Japan. Shogakukan Inc., Tokyo.

Kelaart, E.F. (1853) Prodromus Faunae Zeylanicae. Observer Press, Colombo, 197 pp.

Kipp, S.A. (1959) Die Handflügel-Index als biologisches Mass. Vogelwarte, 20, 77-86.

Legge, W.V. (1878) Spizaetus nipalensis (?). Ibis, 20, 201-204.

Legge, W.V. (1880) A history of the birds of Ceylon. Tisara Prakasakayo Ltd., Dehiwala, Sri Lanka. (reprint 1983), 1624 pp.

Mayr, E. \& Ashlock, P.D. (1991) Principles of systematic zoology. McGraw-Hill, New York, 475 pp.

Naoroji, R. (2006) Birds of prey of the Indian subcontinent. Christopher Helm, London, 692 pp.

Peters, J.L. (1931) Check-list of birds of the world. Vol. 1. Harvard University Press, Cambridge, Massachusetts, 345 pp.

Preleuthner, M. \& Gamauf, A. (1998) A possible new subspecies of the Philippine Hawk-eagle (Spizaetus philippensis) and its future prospects. Journal of Raptor Research, 32, 126-135.

Rasmussen, P.C. (2005) Biogeographic and conservation implications of revised species limits and distributions of South Asian birds. Zoologische Mededelingen, Leiden, 79-3, 137-146.

Rasmussen, P.C. \& Anderton, J.C. (2005) Birds of South Asia: the Ripley guide. 2 vols. Lynx Edicions, Barcelona, 1061 pp.

Sharpe, R.B. (1874) Catalogue of the birds in the British Museum. Vol. 1. Trustees, London, 479 pp.

Sibley, C.G. \& B.L. Monroe, Jr. (1990) Distribution and taxonomy of birds of the world. Yale University Press, New Haven and London, $1111 \mathrm{pp}$.

Warren, R.L.M. (1966) Type-specimens of birds in the British Museum (Natural History). Vol. 1. Non-passerines. Trustees of the British Museum (Natural History), London, 320 pp.

Wattel, J. (1973) Geographical differentiation in the genus Accipiter. Publications of the Nuttall Ornithological Club No. $13,231 \mathrm{pp}$.

Wijesinghe, D.P. (1994) Checklist of the birds of Sri Lanka. Ceylon Bird Club, Colombo, 49 pp.

Zar, J.H. (1999) Biostatistical Analysis-4 ${ }^{\text {th }}$ Edition. Prentice Hall, New Jersey, 663 pp. 


\section{Appendix. Specimens of Nisaetus examined in this study.}

Nisaetus kelaarti: BMNH 1955.6 N20.388, subadult stage 1 male, Sri Lanka; BMNH 1955.6.N.20.389, adult female, Sri Lanka; BMNH 1949.Whi.1.59, adult male, Kuriarkutti, Cochin, India; BMNH 1880.8.19.91, adult male, Mynall, Travancore, India; BMNH 1885.8.1407, subadult stage 2 male, Mynall, Travancore, India; BMNH 85.8.19.1440, juvenile female, Mynall, Travancore, India.

Specimens of $N$. kelaarti examined in photographs: AMNH 534918bis, subadult stage 1 male, near Kandy, Sri Lanka; YPM 43540, unsexed adult, Gammaduwa, Matale, Sri Lanka; BNHS 22931, adult male, Perumal Malai, Palni Hills, India.

Nisaetus nipalensis examined: BMNH 1969-42-12, adult female, Simla, India; BMNH 85.8.19.1346, juvenile male, Sikkim, India; BMNH 85.8.19.1385, unsexed adult, Sikkim, India; BMNH 85.8.19.1392, unsexed adult, Sikkim, India; BMNH 85.8.19.1381 unsexed adult, Sikkim, India; BMNH 85.8.19.1393, unsexed juvenile, Sikkim, India; BMNH 85.8.19.2495, unsexed juvenile, Sikkim, India; BMNH 85.8.19.1389, unsexed juvenile, Sikkim, India; BMNH 85.8.19.1384, unsexed juvenile, Sikkim, India; BMNH 85.8.19.1386, unsexed juvenile, Sikkim, India; BMNH 85.8.19.1382, unsexed juvenile, Sikkim, India; BMNH 85.8.19.1383, unsexed juvenile, Sikkim, India; BMNH 85.8.19.1394, unsexed juvenile, Sikkim, India; BMNH 85.8.19.1348, unsexed subadult, Sikkim, India; BMNH 85.8.19.1344, unsexed juvenile, Sikkim, India; BMNH 85.8.19.1349, unsexed juvenile, Sikkim, India; BMNH 85.8.19.1388, subadult female, Sikkim, India; BMNH 85.8.19.1394, unsexed subadult, Sikkim, India; BMNH 1938.4.15-2194, unsexed adult, Sikkim, India; BMNH 85.8.19.1396, unsexed adult, Sikkim, India; BMNH 85.8.19.1390, unsexed adult, Sikkim, India; BMNH 85.8.19.1380, unsexed juvenile, Sikkim, India; BMNH 85.8.19.1395, unsexed juvenile, Sikkim, India; BMNH 85.8.19.1391, unsexed subadult, Sikkim, India; BMNH 1938.1.15-2193, unsexed juvenile, Sikkim, India; BMNH 385, unsexed subadult, Sikkim, India; BMNH 85.8.19.1364, adult male, Simla, India; BMNH 43.1.13.56, subadult male, Nepal; BMNH 382, unsexed juvenile, Landom Range, Himalaya; BMNH 1949-Whi-1-58, unsexed juvenile, Kurscong, E-Himalaya; BMNH 431.16.63, unsexed juvenile, Nepal; BMNH 85.8.19.1364, adult female, Koleghur, India; BMNH 85.8.19.1361, adult female, Agrore, India; BMNH 85.8.19.1359, adult female, Agrore, India; BMNH 89.11.1.394, adult male, Murree, India; BMNH 43-1-13-68, adult female, Nepal; BMNH 45.1.9.14, adult male, Nepal; BMNH 43.1.13.35, unsexed adult, Nepal; BMNH 80.1.1.1645, unsexed adult, Bootau, India; BMNH 43.1.13.54, unsexed adult, Nepal; BMNH 85.8.19.1406, unsexed adult, Seoni, India; BMNH 43.1.13.62, unsexed juvenile, Nepal; BMNH 85.8.19.1360, adult male, Agrore, India; BMNH 85.8.19.1366, juvenile female, Bussahir, India; BMNH 85.8.19.1365, unsexed subadult, Simla, India; BMNH 85.8.19.1362, unsexed juvenile, Ramgurh, India; BMNH (without number), unsexed juvenile, Nepal. 